\title{
Analisis Kemampuan Akademik Mahasiswa Berdasarkan Latar Belakang Keluarga, Tempat Tinggal, Pertemanan, Sikap Belajar, Konsep Diri, Iklim Kampus, Dan Tenaga Pengajar Dengan Jaringan Syaraf Tiruan Backpropagation
}

\author{
Armansyah*, Guntur Syahputra **, Moch. Iswan Perangin-angin*** \\ * Program Studi Ilmu Komputer, Fakultas Sains dan Teknologi, Universitas Islam Negeri Sumatera Utara Medan \\ ** Program Studi Sistem Informasi, STMIK Triguna Dharma \\ *** Program Studi Manajemen Informasi, STMIK Triguna Dharma
}

\section{Article Info}

\section{Article history:}

Received Jun $12^{\text {th }}, 2020$

Revised Aug 20"th 2020

Accepted Aug 26 ${ }^{\text {th }}, 2020$

\section{Keyword:}

Jaringan Syaraf Tiruan

Backpropagation

IPK

Tingkat Kemampuan Akademis

(Angket) Kuesioner

\begin{abstract}
Dalam hal akademis, Indeks Prestasi Kumulatif (IPK) merupakan tolok ukur prestasi pelajar termasuk mahasiswa. IPK itu sendiri adalah produk hasil dari proses belajar yang diperoleh dari berbagai bentuk evaluasi. Tingginya perolehan IPK mahasiswa kemudian menganggap bahwa mahasiswa dipandang memiliki kemampuan yang baik pula dalam setiap perkuliahan. Namun ternyata anggapan tersebut tidak sepenuhnya benar. Penelitian in i bertujuan untuk memprediksi tingkat kemampuan mahasiswa dalam perkuliahan, terutama untuk matakuliah program studi, khususnya pemrograman. Parameter yang disoroti pada penelitian ini adalah latar belakang keluarga, tempat tinggal, lingkungan pertemanan, sikap belajar, konsep diri, iklim kampus dan tenaga dosen. Kami berpendapat bahwa ketujuh komponen tersebut jika relevan dengan diri mahasiswa dapat memengaruhi tingkat kemampuan mahasiswa. Jaringan Syaraf Tiruan Backpropagation digunakan untuk melatih dan menguji data dari hasil kuesioner berdasarkan ketujuh komponen diatas. Dari beberapa percobaan, keluaran dan target sangat mendekati dengan tingkat akurasi mencapai 99,50\% dengan nilai $M S E$ paling kecil $10^{-7}$ atau 0,0000001 .
\end{abstract}

Corresponding Author:*First Author

Nama : Armansyah

Program Studi : Ilmu Komputer

Universitas Islam Negeri Sumatera Utara 


\section{PENDAHULUAN}

Pandangan tentang hasil belajar menurut pakar bidang pendidikan memiliki makna yang sama meskipun disuguhkan dengan kalimat yang berbeda. Diantaranya, Kunandar, menyebutkan bahwa hasil belajar merupakan kemampuan siswa dalam memenuhi tahapan pengalaman belajar pada suatu kompetensi dasar [1]. Sementara Howard Kingsley di dalam jurnal yang ditulis oleh [2], menguraikan hasil belajar dibagi dalam tiga kategori indikator, yaitu 1) Kompetensi dan kebiasaan; 2) Pengetahuan dan pengertian; 3) Sikap dan cita-cita. Ranah kompetensi dan kebiasaan dipandang sebagai indikator hasil belajar yang baik karena kompetensi memungkinkan siswa mendapatkan kemampuan yang baik pula dalam menyelesaikan permasalahan belajar pada tahap-tahap selanjutnya, dan merubah cara pandang, perilaku dan sikap siswa. Begitupun dengan pengetahuan dan pengertian, akan mempengaruhi kualitas berpikir siswa dalam memutuskan suatu permasalahan belajar. Sementara sikap dan cita-cita mendorong siswa untuk mengembangkan diri, serta mengeksplorasi berbagai hal yang dapat mendukungn ya dimasa mendatang.

Pada sumber lain, Bloom menguraikan pandangannya secara lengkap, dimana menurutnya hasil belajar dapat dilihat berdasarkan indikator kognitif, afektif, psikomotoriknya [3]. Bloom menjelaskan bahwa siswa dipandang memiliki keberhasilan dalam belajar, atau hasil belajar suatu siswa dipandang baik apabila kemampuan kognitif, afektif dan psikomotorik suatu siswa mengalami perubahan pada tingkat yang lebih baik dari sebelumnya. Kemampuan kognitif siswa membantu dalam memberikan kemudahan dalam memahami konsep pengetahuan, kemampuan afektif memungkinkan siswa mampu merubah sikap dan nilai nilai, sementara kemampuan psikomotorik memungkinkan siswa dapat menyelesaikan permasalahan belajar secara praktis yang ditunjukkan pada kinerja secara fisik atau tindakan.

Pandangan-pandangan para pakar tentang hasil belajar diatas, secara umum merujuk kepada kualitas pengetahuan (kognitif), sikap perilaku (afektif), dan juga unjuk kerja siswa (psikomotorik). Ini berarti bahwa semakin baik kemampuan ketiga komponen diatas pada seorang siswa, atau dalam hal ini mahasiswa, maka memiliki peluang memperoleh hasil belajar yang baik pula. Pada jenjang pendidikan tinggi, baik pada skala akademik, sekolah tinggi, institut, maupun pada skala universitas, hasil belajar umumnya ditunjukkan melalui nilai mata kuliah atau secara universal merujuk kepada nilai Indeks Prestasi Kumulatif (IPK). Hal ini sesuai dengan pandangan Nadziruddin (2007) di dalam jurnal yang ditulis oleh Hosniatil H., L. Fadiyah, T., Muzayyanah, dkk, dan, Suheri, menyatakan bahwa kemajuan hasil belajar mahasiswa ditunjukkan melalui nilai indeks prestasi kumulatifnya. Pernyataan bahwa keberhasilan belajar mahasiswa dapat dilihat dari nilai Indeks Prestasi Kumulatif juga merupakan tolok ukur yang ditetapkan oleh Universitas Hasanuddin (UNHAS) yang dituangkan dalam buku peraturan akademik pada pasal 34 ayat 1. Tidak berbeda dengan UNHAS, UIN Sumatera Utara pun demikian. Sehingga nilai IPK sering kali dijadikan salah satu dasar pengambilan keputusan untuk penyeleksian beasiswa peningkatan prestasi mahasiswa disetiap fakultas maupun program studi.

Dari uraian fakta-fakta ilmiah yang sudah disebutkan diawal, dapat ditarik beberapa kesimpulan awal diantaranya : 1) Kemampuan kognitif, afektif, dan psikomotorik yang baik merupakan tolok ukur keberhasilan belajar; 2) Keberhasilan belajar yang tinggi, memengaruhi nilai indeks prestasi yang tinggi pula; 3) Bahwa antara kemampuan dan indeks prestasi memiliki korelasi yang kuat. Kesimpulan tersebut seharusnya benar dan dapat dibuktikan. Namun pada faktanya seringkali simpulan itu bertolak belakang dengan kenyataan yang sesungguhnya. Seperti halnya yang diamati oleh para pembimbing di program studi Ilmu Komputer UIN Sumatera Utara. Data perolehan nilai akademik mahasiswa memperlihatkan nilai indeks prestasi kumulatif yang tergolong baik (tinggi) dengan rata-rata IPK antara 3.25-3.60 dan indeks prestasi semester (IPS) antara nilai 3.25-3.70. Tingginya nilai tersebut ternyata tidak diimbangi dengan kemampuan berpikir, analisi, dan inovasi mahasiswa pada produk-produk karya yang dihasilkan. 
Penelitian ini bertujuan untuk melihat dan memprediksi tingkat kemampuan mahasiswa terhadap perkuliahan, terutama pada perkuliahan dengan mata kuliah program studi seperti pemrograman komputer ditingkat lanjut.

Penelitian ini menggunakan pendekatan Jaringan Syaraf Tiruan (JST) dengan metode backpropagation. JST backpropagation telah banyak digunakan dalam berbagai penelitian. Seperti yang pernah dilakukan oleh Kamil Dimililer (2013) dalam penelitian untuk mengompresi citra medis. Dalam penelitiannya itu, dia membandingkan dua metode kompresi yaitu Haar wavelet transform (HWT) dan Discrete Cosine Transform $(D C T)$. Hasil penelitiannya melaporkan bahwa metode Haar wavelet transform (HWT) yang diterapkannya secara backpropagation menghasilkan produk kompresi citra yang lebih baik dari metode DCT hingga $70 \%$ dengan hasil citra yang masih tampak bersih. Penelitian lain dengan metode backpropagation juga dilakukan oleh Usman, O.L. dan Adenubi, A.O. (2013) untuk memprediksi kemampuan mahasiswa program studi Ilmu Komputer di Tai Solarin University of Education, Ogun State Nigeria. Dalam penelitian tersebut, mereka menggunakan pendekatan JST yang diterapkan dengan nntool pada Matlab untuk memprediksi perolehan nilai mahasiswa. Hasil penelitian mereka menerangkan bahwa JST dan metode backpropagation yang mereka terapkan memperoleh hasil yang baik dengan akurasi hingga 92,7\%.

\section{METODE PENELITIAN}

Dalam penelitian ini penulis menerapkan dua metode yang digunakan berdasarkan fungsinya, yakni metode pengumpulan data dan metode analisis data dengan algoritma backpropagation.

\subsection{Metode Pengumpulan Data}

Pengumpulan data dalam penelitian ini menggunakan metode angket (kuesioner) tertutup. Adapun bentuk instrumennya menggunakan skala likert yang disebar secara online kepada 63 peserta (mahasiswa) di dua kelas yang berbeda dan tingkat yang sama. Adapun bentuk pertanyaan kuesioner berupa pertanyaan berbentuk pilihan yang dipandang sebagai pemicu dan pendorong kemampuan akademik mahasiswa. Beberapa pertanyaan yang tertuang di dalam instrumen adalah tentang frekuensi belajar dan membaca buku, dukungan orangtua, jarak tempat tinggal ke kampus kebebasan berteman, dan lain sebagainya yang tertuang pada 7 komponen berikut : a) faktor latar belakang keluarga; b) lokasi tempat tinggal; c) lingkungan pertemanan; d) sikap belajar; e) iklim sosial kampus; f) staf pembimbing; dan, g) konsep diri. Setiap komponen disajikan dalam 7 pertanyaan pilihan dengan penyajian skalanya mengacu kepada kriteri nilai yang ditampilkan pada Tabel 1.

Tabel 1. Skala pembobotan nilai

\begin{tabular}{lllllc}
\hline & & Kriteria & & Nilai \\
Sangat & Sangat & Sangat & Sangat & Selalu & 4 \\
Baik & Relevan & Sesuai & Setuju & & \\
Baik & Relevan & Sesuai & Setuju & Sering & 3 \\
Cukup & Cukup & Cukup & Cukup & Kadang & 2 \\
Kurang & Kurang & Kurang & Kurang & Tidak & 1 \\
& & & & Pernah & \\
\hline
\end{tabular}

Hasil kuesioner kemudian dihitung untuk menentukan total nilai komponen dengan persamaan :

$$
X=-x 100
$$




\section{Dimana :}

S : Skor perolehan

T : Total Skor

$\mathrm{X}$ : Nilai komponen.

Selanjutnya nilai komponen direratakan dengan persamaan yang mengacu kepada rumus Sujarweni dan Endrayanto (2012) [4] sebagai berikut :

$$
\begin{aligned}
R= & \frac{x_{1} x_{2}+\ldots}{\text { Dimana }:} \quad \underline{+x_{7}}
\end{aligned}
$$

$$
\begin{aligned}
& \mathrm{X} \text { : komponen } \\
& \mathrm{N} \text { : jumlah komponen } \\
& \mathrm{R} \text { : nilai rerata }
\end{aligned}
$$

Nilai rerata dari ketujuh komponen tersebut akan menentukan tingkat kemampuan atau prestasi akademik mahasiswa dengan kriteria mengacu kepada tabel 2.

Tabel 2. Nilai Rerata Komponen Kuesioner

\begin{tabular}{ccll}
\hline RERATA & IPK & \multicolumn{2}{c}{ PREDIKAT BERDASARKAN } \\
KOMPONEN & & PERAMALAN & KETETAPAN UNIVERSITAS \\
\hline $\mathbf{8 6 - 1 0 0}$ & 3,50 & Sangat baik & Terpuji \\
$\mathbf{7 6 - 8 5}$ & 3,01 & Baik & Sangat Memuaskan \\
$\mathbf{6 6 - 7 5}$ & 2,76 & Cukup & Memuaskan \\
$<=\mathbf{6 5}$ & 2,40 & Kurang baik & Baik \\
& 2,00 & & Cukup \\
\hline
\end{tabular}

\subsection{Metode B ackpropagation}

Metode backpropagation pada penelitian ini digunakan untuk menganalisis data melalui pelatihan dan pengujian data. Sebelum pelatihan data dilakukan, data yang diperoleh dari hasil kuesioner dinormalisasikan kedalam bentuk bilangan bipolar dengan rentang antara 1 sampai -1 . Metode normalisasi data latih merujuk kepada metode min-max dengan persamaan berikut

$$
s^{\prime}=\frac{s-\mathrm{mi}}{a x-i} x(0,8)+0,1
$$

\section{ANALISA DAN HASIL}

\subsection{Analisis Data}

Hasil pengumpulan data yang dilakukan melalui angket (kuesioner) berdasarkan 7 komponen yaitu, latar belakang keluarga (X1), tempat tinggal (X2), lingkungan pertemanan (X3), sikap belajar (X4), konsep 
diri (X5), iklim kampus (X6), dan, tenaga dosen (X7), dihitung dengan rumus (13). Ketujuh komponen dihitung kembali dengan rumus (14) untuk mendapatkan nilai rerata komponen. Baik nilai komponen maupun nilai rerata komponen dinormalisasikan dengan rumus (15). Nilai rerata dipasangkan dengan data masukan (X1-X7) sebagai target pelatihan dan pengujian JST Backpropagation dengan arsitektur 7-10-1. Adapun nilai rerata komponen disajikan pada tabel 3, sementara nilai-nilai komponen dan rerata tersebut dinormalisasikan seperti yang ditampilkan pada tabel normalisasi data pada tabel 4.

Tabel 3. Nilai Rerata Komponen Kuesioner

\begin{tabular}{|c|c|c|c|c|c|}
\hline $\begin{array}{c}\text { SAMPE } \\
\text { L }\end{array}$ & RERATA & $\begin{array}{c}\text { TINGKAT } \\
\text { KEMAMPUAN } \\
\text { MAHASISWA }\end{array}$ & $\begin{array}{c}\text { SAMPE } \\
\text { L }\end{array}$ & $\begin{array}{c}\text { RERAT } \\
\text { A }\end{array}$ & $\begin{array}{c}\text { TINGKAT } \\
\text { KEMAMPUAN } \\
\text { MAHASISWA }\end{array}$ \\
\hline MHS_1 & 86 & BAIK & MHS_33 & 93 & BAIK \\
\hline MHS_2 & 89 & BAIK & MHS_34 & 43 & KURANG BAIK \\
\hline MHS_3 & 89 & CUKUP & MHS_35 & 93 & SANGAT BAIK \\
\hline MHS_4 & 89 & BAIK & MHS_36 & 86 & CUKUP \\
\hline MHS_5 & 89 & BAIK & MHS_37 & 57 & KURANG BAIK \\
\hline MHS_6 & 64 & CUKUP & MHS_38 & 75 & CUKUP \\
\hline MHS_7 & 100 & SANGAT BAIK & MHS_39 & 82 & CUKUP \\
\hline MHS_8 & 86 & CUKUP & MHS_40 & 68 & CUKUP \\
\hline MHS_9 & 75 & KURANG BAIK & MHS_41 & 79 & CUKUP \\
\hline MHS_10 & 79 & CUKUP & MHS_42 & 93 & BAIK \\
\hline MHS_11 & 96 & SANGAT BAIK & MHS_43 & 79 & CUKUP \\
\hline MHS_12 & 89 & CUKUP & MHS_44 & 86 & CUKUP \\
\hline MHS_13 & 61 & KURANG BAIK & MHS_45 & 82 & CUKUP \\
\hline MHS_14 & 82 & KURANG BAIK & MHS_46 & 100 & BAIK \\
\hline MHS_15 & 96 & BAIK & MHS_47 & 93 & CUKUP \\
\hline MHS_16 & 93 & BAIK & MHS_48 & 68 & CUKUP \\
\hline MHS_17 & 86 & CUKUP & MHS_49 & 57 & CUKUP \\
\hline MHS_18 & 79 & CUKUP & MHS_50 & 68 & CUKUP \\
\hline MHS_19 & 82 & BAIK & MHS_51 & 75 & KURANG BAIK \\
\hline MHS_20 & 68 & CUKUP & MHS_52 & 89 & BAIK \\
\hline MHS_21 & 96 & BAIK & MHS_53 & 54 & KURANG BAIK \\
\hline MHS_22 & 96 & BAIK & MHS_54 & 71 & CUKUP \\
\hline MHS_23 & 39 & KURANG BAIK & MHS_55 & 75 & KURANG BAIK \\
\hline MHS_24 & 93 & BAIK & MHS_56 & 86 & CUKUP \\
\hline MHS_25 & 64 & CUKUP & MHS_57 & 89 & CUKUP \\
\hline MHS_26 & 50 & CUKUP & MHS_58 & 96 & SANGAT BAIK \\
\hline
\end{tabular}




\begin{tabular}{|l|c|l|l|c|l|}
\hline MHS_27 & 68 & BAIK & MHS_59 & 93 & BAIK \\
\hline MHS_28 & 93 & BAIK & MHS_60 & 96 & BAIK \\
\hline MHS_29 & 68 & KURANG BAIK & MHS_61 & 82 & CUKUP \\
\hline MHS_30 & 75 & BAIK & MHS_62 & 71 & CUKUP \\
\hline MHS_31 & 71 & BAIK & MHS_63 & 89 & BAIK \\
\hline MHS_32 & 86 & CUKUP & & & \\
\hline
\end{tabular}

Tabel 4. Normalisasi data masukan dan target (sumber : kuesioner Desember 2019)

\begin{tabular}{|c|c|c|c|c|c|c|c|c|}
\hline SAMPEL & X1 & $\mathrm{X} 2$ & X3 & X4 & X5 & X6 & $\mathbf{X 7}$ & TARGET \\
\hline MHS_1 & 0,7319 & 0,4378 & 0,6899 & 0,6899 & 0,7739 & 0,7319 & 0,7739 & 0,6899 \\
\hline MHS_2 & 0,7739 & 0,6479 & 0,5218 & 0,5639 & 0,5639 & 0,858 & 0,5639 & 0,6419 \\
\hline MHS_3 & 0,7739 & 0,5218 & 0,5639 & 0,6059 & 0,4798 & 0,816 & 0,4798 & 0,6059 \\
\hline MHS_4 & 0,7739 & 0,4798 & 0,6059 & 0,5639 & 0,5639 & 0,858 & 0,6059 & 0,6359 \\
\hline MHS_5 & 0,7739 & 0,7319 & 0,6059 & 0,6479 & 0,5639 & 0,858 & 0,6059 & 0,6839 \\
\hline MHS_6 & 0,4798 & 0,5639 & 0,6059 & 0,5639 & 0,5639 & 0,7319 & 0,5639 & 0,5819 \\
\hline MHS_7 & 0,9 & 0,5218 & 0,816 & 0,7739 & 0,816 & 0,858 & 0,816 & 0,786 \\
\hline MHS_8 & 0,7319 & 0,3538 & 0,6059 & 0,3958 & 0,5639 & 0,6479 & 0,2697 & 0,5098 \\
\hline MHS_9 & 0,6059 & 0,4798 & 0,3538 & 0,3538 & 0,5639 & 0,6059 & 0,3118 & 0,4678 \\
\hline MHS_10 & 0,6479 & 0,3118 & 0,3958 & 0,4378 & 0,4378 & 0,6899 & 0,6479 & 0,5098 \\
\hline MHS_11 & 0,858 & 0,4798 & 0,816 & 0,7319 & 0,816 & 0,858 & 0,6479 & 0,7439 \\
\hline MHS_12 & 0,7739 & 0,2697 & 0,858 & 0,5639 & 0,6059 & 0,6899 & 0,5218 & 0,6119 \\
\hline MHS_13 & 0,4378 & 0,6899 & 0,1017 & 0,1437 & 0,1437 & 0,3538 & 0,2277 & 0,2998 \\
\hline MHS_14 & 0,6899 & 0,5218 & 0,4798 & 0,4378 & 0,3538 & 0,5639 & 0,3958 & 0,4918 \\
\hline MHS_15 & 0,858 & 0,4378 & 0,7319 & 0,5639 & 0,6479 & 0,816 & 0,6059 & 0,6659 \\
\hline MHS_16 & 0,816 & 0,6059 & 0,5218 & 0,6479 & 0,5218 & 0,858 & 0,6899 & 0,6659 \\
\hline MHS_17 & 0,7319 & 0,7319 & 0,5218 & 0,5218 & 0,5639 & 0,4798 & 0,6479 & 0,5999 \\
\hline MHS_18 & 0,6479 & 0,4798 & 0,4798 & 0,5639 & 0,6059 & 0,858 & 0,3958 & 0,5759 \\
\hline MHS_19 & 0,6899 & 0,816 & 0,6059 & 0,3958 & 0,6059 & 0,858 & 0,6899 & 0,6659 \\
\hline MHS_20 & 0,5218 & 0,5218 & 0,3118 & 0,5218 & 0,6059 & 0,7319 & 0,5218 & 0,5339 \\
\hline MHS_21 & 0,858 & 0,5218 & 0,9 & 0,5218 & 0,6059 & 0,7739 & 0,6059 & 0,6839 \\
\hline MHS_22 & 0,858 & 0,5218 & 0,6059 & 0,6059 & 0,7739 & 0,858 & 0,7319 & 0,7079 \\
\hline MHS_23 & 0,1857 & 0,4378 & 0,2697 & 0,5218 & 0,3118 & 0,1857 & 0,4378 & 0,3358 \\
\hline MHS_24 & 0,816 & 0,4378 & 0,816 & 0,6899 & 0,6059 & 0,6479 & 0,7319 & 0,6779 \\
\hline
\end{tabular}




\begin{tabular}{|c|c|c|c|c|c|c|c|c|}
\hline SAMPEL & X1 & $\mathrm{X} 2$ & $\mathrm{X3}$ & X4 & X5 & X6 & $\mathrm{X} 7$ & TARGET \\
\hline MHS_25 & 0,4798 & 0,7739 & 0,4378 & 0,4798 & 0,3538 & 0,7319 & 0,6899 & 0,5639 \\
\hline MHS_26 & 0,3118 & 0,3958 & 0,5639 & 0,7739 & 0,4798 & 0,7319 & 0,3958 & 0,5218 \\
\hline MHS_27 & 0,5218 & 0,6479 & 0,6479 & 0,6059 & 0,5639 & 0,7739 & 0,5639 & 0,6179 \\
\hline MHS_28 & 0,816 & 0,6479 & 0,6899 & 0,7319 & 0,5639 & 0,816 & 0,7739 & 0,7199 \\
\hline MHS_29 & 0,5218 & 0,6479 & 0,3538 & 0,3118 & 0,4798 & 0,5639 & 0,3958 & 0,4678 \\
\hline MHS_30 & 0,6059 & 0,7739 & 0,6899 & 0,6899 & 0,5639 & 0,7739 & 0,6899 & 0,6839 \\
\hline MHS_31 & 0,5639 & 0,4378 & 0,4798 & 0,6899 & 0,6899 & 0,6479 & 0,816 & 0,6179 \\
\hline MHS_32 & 0,7319 & 0,7319 & 0,3538 & 0,6059 & 0,5218 & 0,5639 & 0,5218 & 0,5759 \\
\hline MHS_33 & 0,816 & 0,6479 & 0,5218 & 0,6059 & 0,6899 & 0,7739 & 0,6059 & 0,6659 \\
\hline MHS_34 & 0,2277 & 0,7319 & 0,2697 & 0,2697 & 0,1857 & 0,5639 & 0,4378 & 0,3838 \\
\hline MHS_35 & 0,816 & 0,6059 & 0,816 & 0,6479 & 0,7319 & 0,7319 & 0,858 & 0,7439 \\
\hline MHS_36 & 0,7319 & 0,7319 & 0,2697 & 0,5218 & 0,5218 & 0,6479 & 0,6059 & 0,5759 \\
\hline MHS_37 & 0,3958 & 0,6479 & 0,3118 & 0,2697 & 0,1437 & 0,3538 & 0,2277 & 0,3358 \\
\hline MHS_38 & 0,6059 & 0,6479 & 0,5639 & 0,4798 & 0,4378 & 0,4798 & 0,7319 & 0,5639 \\
\hline MHS_39 & 0,6899 & 0,5218 & 0,5218 & 0,3538 & 0,4378 & 0,4378 & 0,6479 & 0,5158 \\
\hline MHS_40 & 0,5218 & 0,5218 & 0,5639 & 0,5639 & 0,5639 & 0,4378 & 0,5639 & 0,5339 \\
\hline MHS_41 & 0,6479 & 0,4798 & 0,3538 & 0,6899 & 0,6479 & 0,6479 & 0,5218 & 0,5699 \\
\hline MHS_42 & 0,816 & 0,5639 & 0,6479 & 0,6899 & 0,6059 & 0,7319 & 0,7319 & 0,6839 \\
\hline MHS_43 & 0,6479 & 0,5639 & 0,6899 & 0,4378 & 0,5218 & 0,7739 & 0,4378 & 0,5819 \\
\hline MHS_44 & 0,7319 & 0,4798 & 0,3118 & 0,6059 & 0,6479 & 0,816 & 0,6479 & 0,6059 \\
\hline MHS_45 & 0,6899 & 0,4378 & 0,3958 & 0,4798 & 0,6479 & 0,7739 & 0,7739 & 0,5999 \\
\hline MHS_46 & 0,9 & 0,5218 & 0,6899 & 0,4798 & 0,6059 & 0,7319 & 0,6479 & 0,6539 \\
\hline MHS_47 & 0,816 & 0,3958 & 0,3958 & 0,7319 & 0,5218 & 0,6059 & 0,3958 & 0,5519 \\
\hline MHS_48 & 0,5218 & 0,6059 & 0,6479 & 0,6059 & 0,5639 & 0,7739 & 0,5218 & 0,6059 \\
\hline MHS_49 & 0,3958 & 0,7739 & 0,6479 & 0,3118 & 0,6059 & 0,858 & 0,6059 & 0,5999 \\
\hline MHS_50 & 0,5218 & 0,7739 & 0,4798 & 0,6059 & 0,5639 & 0,7739 & 0,5639 & 0,6119 \\
\hline MHS_51 & 0,6059 & 0,6059 & 0,4798 & 0,1857 & 0,4798 & 0,6479 & 0,4798 & 0,4978 \\
\hline MHS_52 & 0,7739 & 0,7319 & 0,6899 & 0,4798 & 0,5639 & 0,6899 & 0,4378 & 0,6239 \\
\hline MHS_53 & 0,3538 & 0,3538 & 0,2697 & 0,3538 & 0,4378 & 0,6059 & 0,2697 & 0,3778 \\
\hline MHS_54 & 0,5639 & 0,6479 & 0,6899 & 0,2697 & 0,4378 & 0,4798 & 0,4378 & 0,5038 \\
\hline MHS_55 & 0,6059 & 0,5639 & 0,4798 & 0,1857 & 0,2697 & 0,3118 & 0,3118 & 0,3898 \\
\hline MHS_56 & 0,7319 & 0,858 & 0,6059 & 0,4798 & 0,4798 & 0,6479 & 0,4378 & 0,6059 \\
\hline
\end{tabular}




\begin{tabular}{|c|c|c|c|c|c|r|r|c|}
\hline SAMPEL & $\mathbf{X 1}$ & $\mathbf{X 2}$ & $\mathbf{X 3}$ & $\mathbf{X 4}$ & $\mathbf{X 5}$ & $\mathbf{X 6}$ & $\mathbf{X 7}$ & TARGET \\
\hline MHS_57 & 0,7739 & 0,5218 & 0,6479 & 0,3118 & 0,4798 & 0,816 & 0,6479 & 0,5999 \\
\hline MHS_58 & 0,858 & 0,5218 & 0,6479 & 0,816 & 0,816 & 0,7739 & 0,7739 & 0,7439 \\
\hline MHS_59 & 0,816 & 0,5218 & 0,6899 & 0,6479 & 0,5639 & 0,858 & 0,6059 & 0,6719 \\
\hline MHS_60 & 0,858 & 0,4378 & 0,6479 & 0,6899 & 0,5218 & 0,6059 & 0,7319 & 0,6419 \\
\hline MHS_61 & 0,6899 & 0,4378 & 0,5218 & 0,5639 & 0,5218 & 0,4798 & 0,7319 & 0,5639 \\
\hline MHS_62 & 0,5639 & 0,5639 & 0,2277 & 0,3958 & 0,5639 & 0,858 & 0,7319 & 0,5579 \\
\hline MHS_63 & 0,7739 & 0,7739 & 0,6059 & 0,5639 & 0,5218 & 0,5639 & 0,5639 & 0,6239 \\
\hline
\end{tabular}

\subsection{Hasil}

Dari tabel normalisasi masukan dan target diatas, data latih diambil dari MHS_1 sampai MHS_53, sementara data pengujian diambil dari MHS_54 sampai dengan MHS_63 dengan hasil pelatihan yang sangat baik. Adapun sebaran data keluaran, target, dan error jaringan (MSE) ditampilkan pada tabel 5. Dari proses pelatihan data diperoleh $M S E 10^{-7}$ atau 0,0000001 yang terjadi pada epoch ke 14 seperti yang ditampilkan pada grafik pelatihan di gambar 1 .

Tabel 5. Pelatihan data

\begin{tabular}{|c|c|c|c|c|c|c|c|}
\hline SAMPEL & TARGET & OUTPUT & MSE & SAMPEL & TARGET & OUTPUT & MSE \\
\hline MHS_1 & 0,6899 & 0,6899 & 0,0000 & MHS_28 & 0,7199 & 0,7204 & $-0,0005$ \\
\hline MHS_2 & 0,6419 & 0,6425 & $-0,0006$ & MHS_29 & 0,4678 & 0,4678 & 0,0000 \\
\hline MHS_3 & 0,6059 & 0,6069 & $-0,0010$ & MHS_30 & 0,6839 & 0,6835 & 0,0004 \\
\hline MHS_4 & 0,6359 & 0,6366 & $-0,0007$ & MHS_31 & 0,6179 & 0,6181 & $-0,0002$ \\
\hline MHS_5 & 0,6839 & 0,6841 & $-0,0002$ & MHS_32 & 0,5759 & 0,5761 & $-0,0002$ \\
\hline MHS_6 & 0,5819 & 0,5825 & $-0,0006$ & MHS_33 & 0,6659 & 0,6655 & 0,0004 \\
\hline MHS_7 & 0,7860 & 0,7807 & 0,0053 & MHS_34 & 0,3838 & 0,3409 & 0,0429 \\
\hline MHS_8 & 0,5098 & 0,5027 & 0,0071 & MHS_35 & 0,7439 & 0,7443 & $-0,0004$ \\
\hline MHS_9 & 0,4678 & 0,4670 & 0,0008 & MHS_36 & 0,5759 & 0,5760 & $-0,0001$ \\
\hline MHS_10 & 0,5098 & 0,4878 & 0,0220 & MHS_37 & 0,3358 & 0,3071 & 0,0287 \\
\hline MHS_11 & 0,7439 & 0,7452 & $-0,0013$ & MHS_38 & 0,5639 & 0,5640 & $-0,0001$ \\
\hline MHS_12 & 0,6119 & 0,6107 & 0,0012 & MHS_39 & 0,5158 & 0,5235 & $-0,0077$ \\
\hline MHS_13 & 0,2998 & 0,3003 & $-0,0005$ & MHS_40 & 0,5339 & 0,5566 & $-0,0227$ \\
\hline MHS_14 & 0,4918 & 0,4919 & $-0,0001$ & MHS_41 & 0,5699 & 0,5554 & 0,0145 \\
\hline MHS_15 & 0,6659 & 0,6665 & $-0,0006$ & MHS_42 & 0,6839 & 0,6768 & 0,0071 \\
\hline
\end{tabular}




\begin{tabular}{|c|c|c|c|c|c|c|c|} 
MHS_16 & 0,6659 & 0,6659 & 0,0000 & MHS_43 & 0,5819 & 0,5826 & $-0,0007$ \\
\hline MHS_17 & 0,5999 & 0,5997 & 0,0002 & MHS_44 & 0,6059 & 0,6063 & $-0,0004$ \\
\hline MHS_18 & 0,5759 & 0,5763 & $-0,0004$ & MHS_45 & 0,5999 & 0,5871 & 0,0128 \\
\hline MHS_19 & 0,6659 & 0,6668 & $-0,0009$ & MHS_46 & 0,6539 & 0,6552 & $-0,0013$ \\
\hline MHS_20 & 0,5339 & 0,5338 & 0,0001 & MHS_47 & 0,5519 & 0,5520 & $-0,0001$ \\
\hline MHS_21 & 0,6839 & 0,6846 & $-0,0007$ & MHS_48 & 0,6059 & 0,6062 & $-0,0003$ \\
\hline MHS_22 & 0,7079 & 0,7088 & $-0,0009$ & MHS_49 & 0,5999 & 0,6055 & $-0,0056$ \\
\hline MHS_23 & 0,3358 & 0,3126 & 0,0232 & MHS_50 & 0,6119 & 0,6124 & $-0,0005$ \\
\hline MHS_24 & 0,6779 & 0,6632 & 0,0147 & MHS_51 & 0,4978 & 0,4979 & $-0,0001$ \\
\hline MHS_25 & 0,5639 & 0,5529 & 0,0110 & MHS_52 & 0,6239 & 0,6249 & $-0,0010$ \\
\hline MHS_26 & 0,5218 & 0,5220 & $-0,0002$ & MHS_53 & 0,3778 & 0,3781 & $-0,0003$ \\
\hline MHS_27 & 0,6179 & 0,6178 & 0,0001 & & & & \\
\hline
\end{tabular}

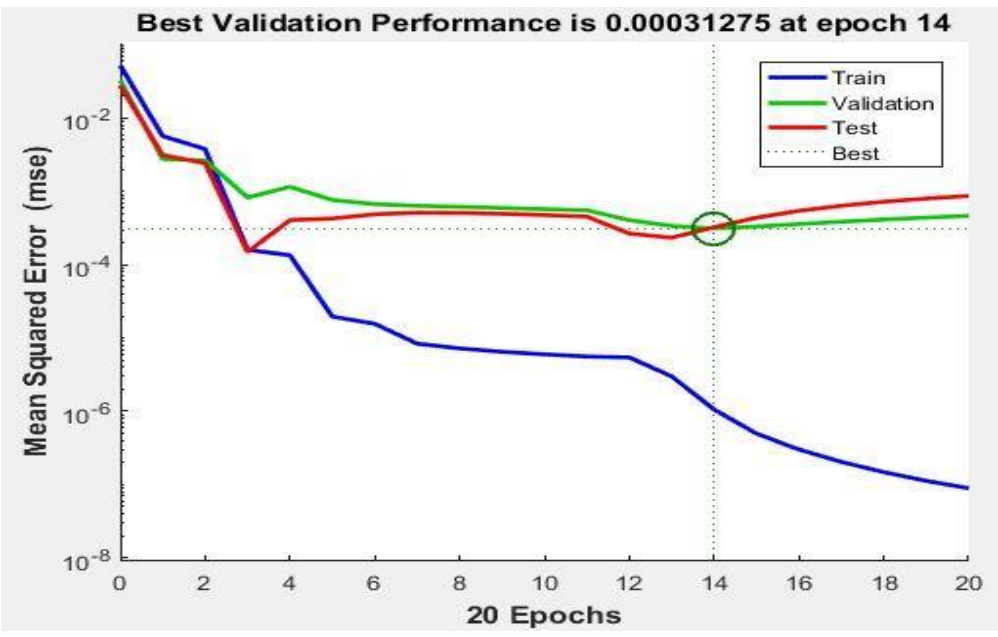

Gambar 1. Mean Squared Error

Dari pelatihan data yang telah dilakukan, pengujian dilakukan kembali terhadap 10 data sampel yakni MHS_54 sampai data MHS_63 yang telah dinormalisasikan. Dari pengujian didapati bahwa data keluaran (output) menampilkan nilai yang hampir sama dengan nilai target seperti yang ditampilkan pada tabel 6. Ini artinya JST Backpropagation berhasil melakukan pelatihan dan pengujian terhadap pola data yang ada. Dalam hal peramalan tingkat kemampuan akademik mahasiswa terhadap mata kuliah yang diberikan, pendekatan JST dengan metode ini dapat melakukan prediksi sangat baik dengan kinerja pelatihan hingga 99,99\%, validasi terhadap regresi 99,42\%, pengujian data 99,50\%. Tabel 7 adalah data IPK 63 mahasiswa dalam sampel penelitian ini yang diambil dari data semester gasal 2019/2020. Jika data IPK tersebut dicocokan dengan tabel predikat (Tabel 2) diatas disimpulkan bahwa kemampuan akademik mahasiswa relevan dengan peramalan bahkan melampau.

Tabel 6. Pengujian data sampel

\begin{tabular}{|c|c|c|c|c|c|}
\hline SAMPEL & TARGET & OUTPUT JST & SAMPEL & TARGET & OUTPUT JST \\
\hline MHS_54 & 0,5109 & 0,5038 & MHS_59 & 0,6704 & 0,6719 \\
\hline MHS_55 & 0,3455 & 0,3898 & MHS_60 & 0,6230 & 0,6419 \\
\hline
\end{tabular}




\begin{tabular}{|c|c|c|c|c|c|} 
MHS_56 & 0,6086 & 0,6059 & MHS_61 & 0,5649 & 0,5639 \\
\hline MHS_57 & 0,6017 & 0,5999 & MHS_62 & 0,5841 & 0,5579 \\
\hline MHS_58 & 0,7766 & 0,7439 & MHS_63 & 0,6209 & 0,6239 \\
\hline
\end{tabular}

Tabel 7. Data IPK Mahasiswa Semester Gasal 2019/2020

\begin{tabular}{|c|c|c|c|c|c|c|c|c|c|c|c|}
\hline MHS & $\begin{array}{l}\text { IP } \\
\mathbf{K}\end{array}$ & MHS & $\begin{array}{l}\mathbf{I P} \\
\mathbf{K}\end{array}$ & MHS & $\begin{array}{l}\text { IP } \\
\text { K }\end{array}$ & MHS & $\begin{array}{l}\text { IP } \\
\mathbf{K}\end{array}$ & MHS & $\begin{array}{l}\text { IP } \\
\mathbf{K}\end{array}$ & MHS & $\begin{array}{l}\text { IP } \\
\mathbf{K}\end{array}$ \\
\hline & 3,3 & MHS_1 & 3,2 & MHS_2 & 3,4 & MHS_3 & 2,9 & MHS_4 & 3,3 & MHS_5 & 3,1 \\
\hline MHS_1 & 1 & 2 & 4 & 3 & 4 & 4 & 2 & 5 & 9 & 6 & 5 \\
\hline & 3,6 & MHS_1 & 3,0 & MHS_2 & 3,2 & MHS_3 & 3,5 & MHS_4 & 3,3 & MHS_5 & 2,9 \\
\hline MHS_2 & 3 & 3 & 3 & 4 & 3 & 5 & 5 & 6 & 2 & 7 & 9 \\
\hline & 3,4 & MHS_1 & 3,7 & MHS_2 & 3,4 & MHS_3 & 3,1 & MHS_4 & 3,3 & MHS_5 & 3,4 \\
\hline MHS_3 & 5 & 4 & 2 & 5 & 0 & 6 & 3 & & 0 & & 5 \\
\hline & 3,5 & MHS_1 & 3,3 & MHS_2 & 3,4 & MHS_3 & 3,1 & MHS_4 & 3,3 & MHS_5 & 3,2 \\
\hline MHS_4 & 4 & 5 & 1 & 6 & 8 & 7 & 7 & & 7 & 9 & 8 \\
\hline & 3,6 & MHS_1 & 3,2 & MHS_2 & 3,2 & MHS_3 & 3,4 & MHS_4 & 2,9 & MHS_6 & 3,5 \\
\hline MHS_5 & 1 & 6 & 8 & 7 & 9 & 8 & 5 & 9 & 3 & 0 & 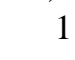 \\
\hline & 3,2 & MHS_1 & 3,3 & MHS_2 & 3,4 & MHS_3 & 2,7 & MHS_5 & 3,2 & MHS_6 & 3,6 \\
\hline MHS_6 & 3 & 7 & 3 & 8 & 4 & 9 & 8 & 0 & 9 & 1 & 3 \\
\hline & 3,2 & MHS_1 & 3,2 & MHS_2 & 3,2 & MHS_4 & 3,6 & MHS_5 & 3,1 & MHS_6 & 3,2 \\
\hline MHS_7 & 0 & 8 & 6 & 9 & 2 & 0 & 6 & 1 & 0 & 2 & 0 \\
\hline & 3,2 & MHS_1 & 3,3 & MHS_3 & 3,2 & MHS_4 & 3,3 & MHS_5 & 2,8 & MHS_6 & 3,0 \\
\hline MHS_8 & 6 & 9 & 0 & 0 & 1 & 1 & 0 & 2 & 8 & 3 & 5 \\
\hline & 3,2 & MHS_2 & 3,5 & MHS_3 & 3,5 & MHS_4 & 3,4 & MHS_5 & 3,4 & & \\
\hline MHS_9 & 9 & 0 & 0 & 1 & 7 & 2 & 8 & 3 & 2 & & \\
\hline MHS_1 & 3,3 & MHS_2 & 3,4 & MHS_3 & 3,2 & MHS_4 & 3,3 & MHS_5 & 3,1 & & \\
\hline 0 & 6 & 1 & 4 & 2 & 6 & 3 & 7 & 4 & 3 & & \\
\hline MHS_1 & 3,3 & MHS_2 & 3,4 & MHS_3 & 3,4 & MHS_4 & 3,5 & MHS_5 & 2,9 & & \\
\hline 1 & 5 & 2 & 0 & 3 & 7 & 4 & 4 & 5 & 2 & & \\
\hline
\end{tabular}

(sumber : prodi. Ilmu Komputer UINSU)

\section{KESIMPULAN}

Dari beberapa percobaan yang dilakukan terhadap nilai rerata komponen kuesioner, JST backpropagation bekerja sangat baik dalam melakukan peramalan kemampuan akademik dan prestasi akademik mahasiswa berdasarkan faktor-faktor : latar belakang keluarga, tempat tinggal, lingkungan pertemanan, sikap belajar, konsep diri, iklim kampus dan tenaga dosen, dengan MSE sangat kecil yakni, $10^{-6}$ atau 0,0000001. Pelatihan dan pengujian data dengan nntool pada matlab R2016b x64 menghasilkan nilai output jaringan yang hampir sama dengan data target yang diharapkan, bahkan pada tahap pelatihan, beberapa data output tampak sama dengan targetnya.

\section{UCAPAN TERIMA KASIH}

Dalam penelitian ini tidak terlepas dari bantuan pihak-pihak terkait, untuk kami mengucapkan terima kasih kepada orang-orang yang telah banyak memberikan waktu dan pikirannya. 


\section{REFERENSI}

[1] I. Ayuwanti, "Meningkatkan Aktivitas dan Hasil Belajar Matematika Menggunakan Model Pembelajaran Kooperatif Tipe Group Investigation di SMK Tuma'ninah Yasin Metro," SAP (Susunan Artik. Pendidikan), vol. 1, no. 2, pp. 105-114, 2017, doi: 10.30998/sap.vli2.1017.

[2] Sulastri, Imran, and A. Firmansyah, "Meningkatkan hasil belajar siswa melalui strategi pembelajaran berbasis masalah pada mata pelajaran IPS di Kelas V SDN 2 limbo makmur kecamatan bumi raya," $J$. Kreat. Tadulako Online, vol. 3, no. 1, pp. 90-103, 2015.

[3] \& H. Sasmi, W.Y., Johan, S.R, "the Influence of Learning Motivation and Learning Outcomes on the Interest To Continue Studies To College in the Students of Class Xii Smk Negeri 5,” vol. 2, pp. 1-13.

[4] dan D. Alwan, Menza Hendri, "Faktor-Faktor Yang Mendorong Siswa MIA SMAN Mengikuti Bimbingan Belajar Luar Sekolah Di Kecamatan Telanaipura Kota Jambi,” vol. 02, no. 01, pp. 244-256, 2017. 